\title{
Public Service Satisfaction on Hajj-Related Services in Indonesia: Demographic Analysis
}

\author{
Reza Fathurrahman ${ }^{1}$, Zaenal Abidin ${ }^{2}$, Anisa Dwi Utami ${ }^{3}$ \\ ${ }^{1}$ Fakultas Ilmu Administrasi, Universitas Indonesia, J1. Prof. Dr. Selo Soemardjan, Depok 16424, \\ Indonesia, rezafathurrahman@ui.ac.id \\ ${ }^{2}$ Badan Litbang dan Diklat, Kementerian Agama RI, JL M.H Thamrin Nomor 6, Jakarta Pusat 10230, \\ Indonesia, zaenalabidin@kemenag.go.id \\ ${ }^{3}$ Center for Islamic Business and Economic Studies (CIBEST), Institut Pertanian Bogor, Jalan Raya \\ Padjadjaran, Bogor 16151, Indonesia, anisadwiutami@apps.ipb.ac.id
}

\begin{abstract}
Measurement of public service satisfaction with government services serves as a valuable reflecting point for public officials to improve the public service quality. Pilgrimage to Mecca and Medina in Saudi Arabia is considered as a national duty and government responsibility in countries with a significant number of Muslim citizens. This article analyzes primary data from the 2019 national public service satisfaction survey on hajj-related services within Indonesian territory collected by the Ministry of Religious Affairs to examine variation across demographic backgrounds. 1,491 respondents participated in the survey representing individual appraisals toward various services during departure and returning phases. The main focus of investigation are the six selected service dimensions, namely, 1) Individual capability, 2) Ease of access to information, 3) Service procedures, 4) Speed of service, 5) Facilities and infrastructure, and 6) Cost-related perception. The results of regression analysis support diverse roles of demographic variables in explaining variance in public service satisfaction feedback. The empirical findings suggest that people with a higher-level education are more likely to experience less satisfaction. Meanwhile, females are likely to perceive higher satisfaction with the provided services than the males.
\end{abstract}

Keywords: Demographic analysis, hajj, Indonesian government, public service satisfaction.

\begin{abstract}
Abstrak. Pengukuran tingkat kepuasan publik terhadap pelayanan yang disediakan oleh pemerintah merupakan sebuah sarana yang penting bagi aparatur negara dalam meningkatkan kualitas pelayanan publik. Ibadah haji dari Mekkah ke Madinah di Arab Saudi merupakan sebuah tugas nasional dan tanggung jawab pemerintah di negara-negara dengan tingkat penduduk Muslim yang tinggi. Artikel ini menganalisis data primer yang diambil dari survei kepuasan publik terhadap layanan haji 2019 yang dikumpulkan oleh Kementerian Agama sebagai basis untuk mengetahui variasi antara responden dengan latar belakang demografi yang berbeda. 1,491 responden berpartisipasi dalam survey tersebut yang mencerminkan penilaian individu jemaah terhadap beragam layanan baik pada fase keberangkatan maupun kepulangan. Fokus utama dari penelitian ini berada pada enam dimensi pelayanan, yaitu: 1) Kapabilitas individual petugas, 2) Kemudahan akses informasi, 3) Prosedur layanan, 4) Kecepatan layanan, 5) Fasilitas dan infrastruktur, dan 6) Persepsi terhadap pembiayaan. Secara umum, hasil analisis regresi mendukung adanya berbagai peran dari sejumlah variabel demografi dalam menjelaskan variasi dari umpan balik kepuasan layanan publik yang diberikan. Temuan empiris menemukan bahwa jemaah dengan tingkat pendidikan yang lebih tinggi cenderung memiliki kepuasan yang relatif lebih rendah. Selain itu, responden wanita memiliki kecenderungan untuk memberikan penilaian kepuasan yang lebih tinggi terhadap layanan yang diberikan bila dibandingkan dengan lakilaki.
\end{abstract}

Kata kunci: Analisis demografi, haji, kepuasan publik, pemerintah Indonesia.

\section{INTRODUCTION}

Hajj is the fifth pillar of Islam for Muslims who have successfully fulfilled the physical and economic conditions to travel and perform a series of worship or religious rituals in the holiest place (Mecca and its surrounding) at a certain period. In accordance with Article 10, Paragraph (1) of Law No. 8/2019 on the Administration of Hajj and Umrah, the Hajj Administration must be coordinated by the

AL-MUZARA'AH Vol. 9 No. 1, 2021 
national government through the establishment of taskforce working units at regional and national level, as well as in Saudi Arabia. At the first line level, the national government creates the Hajj Administration Officers (PPIH) who are responsible for providing guidance, service, and protection, as well as controlling and coordination of Hajj-related operations in the country and/or in Saudi Arabia.

Ensuring a successful annual hajj pilgrimage has been a part of national government's responsibility both domestically (within Indonesian territory) and abroad (while the pilgrims are in Saudi Arabia). As the number of hajj pilgrims has been steadily increasing from year to year, therefore the government must always try its best to conduct various necessary efforts to improve capacity and quality of the hajj pilgrimage. In 2019 alone, before the Covid-19 Pandemic, 212,732 citizens performed the hajj (Ministry of Religious Affairs, 2019). According to the Law No.25/2009, the implementation of annual hajj pilgrimage must be thoroughly evaluated. The Ministry of Administrative Reform (2017) has also introduced a ready-to-use instrument to measure citizen satisfaction index.

Pursuant to the Law No. 25/2009, Paragraph (10), public service satisfaction survey is required for three main purposes: Firstly, to collect individual feedback towards various hajj-related services; secondly, to highlight unsatisfactory aspects from the eyes of citizens; and also to investigate which aspects may significantly influence the overall pilgrim's satisfaction. Until this point, the Ministry of Religious Affairs has successfully conducted three annual public service satisfaction surveys for three years in a row $(2017,2018,2019)$ involving a large number of respondents. The survey items were developed based on the guideline issued by the Ministry of Administrative Reform to measure public service satisfaction index incorporating nine evaluation aspects (Ministry of Administrative Reform, 2017).

This article, in particular, attempts to examine the extent to which citizen's individual demographic backgrounds may affect their perceived individual ratings to hajj-related services. For the purpose of this study, we have selected six key service dimensions that were derived from the existing items of survey instrument to be further investigated, including: Individual capability; service procedures; speed of service; ease of access to information; facilities and infrastructure; and cost-related perception (see Berry et al., 1990; Ministry of Administrative Reform, 2017). The main research question is as follows: Are there significant differences among demographic groups of citizens regarding their satisfaction with hajj-related services?

\section{LITERATURE REVIEW}

The word "satisfaction" derives from two Latin words "satis" which means relatively okay, adequate, and "facio" which is defined as to do or to create. In brief, satisfaction can be described as "an effort to fulfill a particular thing" (Tjiptono and Chandra, 2005). Satisfaction in public services can also be related to the similar concept introduced in the private sector. Therefore, if the performance/service delivery meets the citizens' expectations then they will be satisfied. On the contrary, if the service provider fails to fulfill the expectations, then they will be disappointed. Meanwhile "service" refers to taking care of someone's needs" (Tjiptono and Chandra, 2005).

Public service satisfaction with government services, despite its subjectivity, is still widely used and considered useful to inform policy makers on possible rooms for improvement (de Walle, 2018; Bouckaert et al., 2005). As it also represents citizen's aggregate interests, public service satisfaction surveys can help public officials to improve their understanding on public preferences, to examine policy effectiveness, and to plan future policies (Collins et al., 2019). Moreover, a number of scholars have suggested an interrelated link between satisfaction with service delivery, as indicated from high score in citizen-based survey, and trust in government (for instance, Christensen et al., 2020; Kampen et al., 2006; Shockley-Zalabak et al., 2010; Yang and Holzer, 2006; Vigoda-Gadot and Yuval., 2003). 
Finally, the expected consequences of high citizen's trust in government are that it will bring more government support in return. In other words, a hope to win back citizen trust in government has become a natural force for the government to conduct a public service satisfaction survey.

Consistent with the satisfaction and trust argument described above, Nicholls et al. (1998) underscore that customer satisfaction remains pivotal for ensuring continued survival of both private and public organizations. In the private sector, marketers assess customers' individual expectations in regular basis to prevent growing customer dissatisfaction which may in turn potentially jeopardize their profit maximization goals (Zeithaml et al., 2018; Rouf et al., 2018). Public service organizations, on the other side, cannot resist from public's demand on continuous service improvement, especially considering rapid changes in technology and citizen expectation (Martinovic et al., 2017; Donelly et al., 1995; Brysland and Curry, 2001). Failure to satisfy citizens' expectation towards specific public services may potentially lead to lower trust in government (Murtin et al., 2018).

In the context of hajj administration, service can also be defined as "taking care of anything that is needed by the pilgrims during their hajj pilgrimage from their starting point in Indonesia, and also during their trip to Saudi Arabia until they return back home. According to Tjiptono (2002), hajj administrators must fulfill the following elements to maintain the satisfaction of the pilgrims: 1) Identify who the recipients of its services are; 2) understand the level of expectation; 3) understand the service quality strategy; 4) understand the measurement cycle and feedback on satisfaction.

Public service satisfaction with particular services has been widely studied, but demographic analysis to better understand individual responses to specific hajj-related service dimensions seems still lacking. Previous studies reveal that customers' demographic profile remains as one of the most responsible factors for the variation of perceived service quality and satisfaction (Psomas et al., 2020; Rouf et al., 2018). It is very important to consider that the demographic profile of citizens who perform hajj may also change from time to time. In the case of Indonesia, for instance, in 2019 there were more than $60 \%$ of hajj pilgrims belong to the elder group (Abdi, 2019), and 55\% male or equal to more than 1.3 million people (Setiawan, 2019).

In practical situation, what could happen if government neglected or was not well informed about this pilgrim statistical figure? There might be a greater chance that the service being provided may fail to fulfill the expectation. The same case may occur if policy makers ignore demographic facts while reading a report derived from the most recent public satisfaction survey. They may lose invaluable data to adequately understand the survey results and this may potentially lead to ineffective policy formulation and adoption. Radu et al. (2018) and Young et al. (2000), among others, may serve as practical examples on how demographic data embedded within a service satisfaction survey supports the development of managerial strategies and policies. It is argued that in order to meet the public service expectation and also to understand public preferences, the government should also consider the demographic factors among service recipients.

\section{METHODS}

This study used cross-sectional data from the national survey in 2019 measuring the level of hajj pilgrim satisfaction in Indonesia. The researchers drew a sample size of $n$ from the hajj pilgrim population using simple random sampling towards the pilgrims both during arrival and departure phases. After excluding the data's missing values, the empirical technique was employed using 1,491 respondents from both arrival and departure sampling.

In this research, the hajj service satisfaction is constructed by the six dimensions, namely 1) Individual capability (IC), 2) Service procedures (SP), 3) Speed of service (T), 4) Ease of access to information (I), 5) Facilities and infrastructure (F), and 6) Cost-related perception (CP). Each dimension reflects the national hajj survey questionnaire's key points explaining the customers' 
perceived satisfaction with the provided hajj-related services within Indonesia's domestic territory measured by using Likert scale with the value from 1 to 4 . The value of 1 represents the highest level of satisfaction, while the value of 4 represents the lowest level respectively. Subsequently, the total hajj satisfaction score is then calculated by the mean value of those six dimensions.

Regression analysis was conducted to investigate the role of demographic factors in explaining the hajj service satisfaction. To this aim, seven regression models were developed by constructing each dimension and the total score of satisfaction as the dependent variables. Meanwhile, the independent variables are from the respondents' demographic factors, including age, gender, marital status, level of education, and type of job. In addition, a dummy variable, namely arrival, is also constructed as the independent variable to evaluate whether there is a difference between arrival and departure samples, with the value of 1 representing the sample from the arrival phase, and 0 is the opposite i.e. the departure phase. Table 1 shows the detailed description of the variables.

Table 1 The description of variables

\begin{tabular}{|c|c|c|}
\hline Variable & \multicolumn{2}{|c|}{ Description } \\
\hline Gender & $\begin{array}{l}1=\text { male } \\
2=\text { female }\end{array}$ & \\
\hline Age & $\begin{array}{l}1=\text { under } 20 \text { years old } \\
2=20-29 \text { years old } \\
3=30-39 \text { years old }\end{array}$ & $\begin{array}{l}4=40-49 \text { years old } \\
5=50-59 \text { years old } \\
6=\text { more than } 60 \text { years old }\end{array}$ \\
\hline Married & $\begin{array}{l}1=\text { married } \\
2=\text { single }\end{array}$ & $3=$ widow or doubt \\
\hline Education & $\begin{array}{l}1=\text { unschooled } \\
2=\text { not graduated from } \\
\text { elementary school } \\
3=\text { elementary school } \\
4=\text { junior high school }\end{array}$ & $\begin{array}{l}5=\text { senior high school } \\
6=\text { diploma } \\
7=\text { bachelor } \\
8=\text { master } \\
9=\text { doctor }\end{array}$ \\
\hline Type of job & $\begin{array}{l}1=\text { ASN/TNI/POLRI } \\
2=\text { Teacher } \\
3=\text { Private employee } \\
4=\text { Entrepreneur } \\
5=\text { Student }\end{array}$ & $\begin{array}{l}6=\text { Housewife } \\
7=\text { Retired person } \\
8=\text { Farmer/fisherman } \\
9=\text { Other occupations }\end{array}$ \\
\hline Arrival & $\begin{array}{l}1=\text { surveyed on arrival } \\
0=\text { surveyed on departure }\end{array}$ & \\
\hline IC & Individual capability, with & $=$ very capable \\
\hline SP & Service procedure, with $1=$ & ery simple \\
\hline $\mathrm{T}$ & Speed of services, with $1=$ & he quickest service \\
\hline I & Ease of access to informati & n, with $1=$ very easy \\
\hline $\mathrm{F}$ & Facilities and infrastructur & with $1=$ very good \\
\hline $\mathrm{CP}$ & Cost perception, with $1=\mathrm{th}$ & cost is very cheap \\
\hline Total & $\begin{array}{l}\text { The hajj service satisfactio } \\
\text { I, F, CP }\end{array}$ & $=$ the mean value of IC, SP, T, \\
\hline
\end{tabular}


In general, the regression model is explained as the following equation:

$$
\begin{aligned}
& \text { Hajj Satisfaction }=\beta_{01}+\beta_{11} \text { gender }+\beta_{21} \text { age }+\beta_{31} \text { married }+\beta_{41} \text { education }+\beta_{51} \text { job }+\beta_{61} \\
& \text { arrival }+u 1
\end{aligned}
$$

where $\beta_{11}, \beta_{21}, \beta_{31}, \beta_{41}, \beta_{51}$, and $\beta_{61}$ are the estimated coefficients for each independent variable, and $u 1$ is the error term of the regression model. Subsequently, the empirical investigation is conducted by evaluating the statistically significance for each independent variable based on the test of t-statistics where the null hypothesis is there is no effect of the respective independent variable (for example i.e. $\beta_{11}=0$ ). Therefore, the rejection of the null hypothesis implies that the independent variable likely has a significant effect on the dependent variable. Meanwhile, for the overall model, the evaluation is referred to the F statistics.

Furthermore, as mentioned earlier, in order to capture the role of demographic factors on each dimension of the hajj service satisfaction, the following equations represents the empirical model of regression analysis:

$$
\begin{aligned}
& \text { IC }=\beta_{02}+\beta_{12} \text { gender }+\beta_{22} \text { age }+\beta_{32} \text { married }+\beta_{42} \text { education }+\beta_{52} \text { job }+\beta_{62} \text { arrival }+u 2 \\
& \mathrm{SP}=\beta_{03}+\beta_{13} \text { gender }+\beta_{23} \text { age }+\beta_{33} \text { married }+\beta_{43} \text { education }+\beta_{53} \text { job }+\beta_{63} \text { arrival }+u 3 \\
& T=\beta_{04}+\beta_{14} \text { gender }+\beta_{24} \text { age }+\beta_{34} \text { married }+\beta_{44} \text { education }+\beta_{54} \text { job }+\beta_{64} \text { arrival }+u 4 \\
& I=\beta_{05}+\beta_{15} \text { gender }+\beta_{25} \text { age }+\beta_{35} \text { married }+\beta_{45} \text { education }+\beta_{55} \text { job }+\beta_{65} \text { arrival }+u 5 \\
& F=\beta_{06}+\beta_{16} \text { gender }+\beta_{26} \text { age }+\beta_{36} \text { married }+\beta_{46} \text { education }+\beta_{56} \text { job }+\beta_{66} \text { arrival }+u 6 \\
& C P=\beta_{07}+\beta_{17} \text { gender }+\beta_{27} \text { age }+\beta_{37} \text { married }+\beta_{47} \text { education }+\beta_{57} \text { job }+\beta_{67} \text { arrival }+u 7
\end{aligned}
$$

Based on the abovementioned model, the following hypotheses were tested in this study:

H1: Gender-related differences are expected to attribute different degrees of satisfaction to varying dimensions of hajj-related services

H2: Age-related differences are expected to attribute different degrees of satisfaction to varying dimensions of hajj-related services

H3: Marriage-related differences are expected to attribute different degrees of satisfaction to varying dimensions of hajj-related services

$H 4$ : Education-related differences are expected to attribute different degrees of satisfaction to varying dimensions of hajj-related services

H5: Job-related differences are expected to attribute different degrees of satisfaction to varying dimensions of hajj-related services

H6: Survey-period differences are expected to attribute different degrees of satisfaction to varying dimensions of hajj-related services

\section{RESULTS AND DISCUSSION}

As mentioned in the method section, the hajj service satisfaction is calculated by focusing on the six dimensions, i.e., 1) Individual capability (IC), 2) Service procedures (SP), 3) Speed of service (T), 4) Ease of access to information (I), 5) Facilities and infrastructure (F), and 6) Cost-related perception (CP). Based on this conceptual model, the findings suggest that the level of satisfaction of hajj service is good with the average value being 1.79. Table 2 explains the summary statistics for all variables. As shown in Table 2, generally, the findings reveal that most dimensions have a good level of satisfaction, mostly less than 2. Moreover, the individual capability dimension (IC) and the service procedure (SP) are the most satisfied dimensions with the lowest value compared to the other dimensions. Meanwhile, the cost perception (CP) has the highest score, which implies the least satisfaction, though the score is also less than 2 . 
Table 2 Summary statistics of the variables

\begin{tabular}{cccccc}
\hline Variable & Mean & Median & S.D. & Min & Max \\
\hline Gender & 1.49 & 1.00 & 0.500 & 1.00 & 2.00 \\
Age & 4.48 & 5.00 & 1.04 & 1.00 & 6.00 \\
Married & 1.14 & 1.00 & 0.495 & 1.00 & 7.00 \\
Education & 5.68 & 5.00 & 1.66 & 1.00 & 9.00 \\
Job & 4.20 & 4.00 & 2.34 & 1.00 & 9.00 \\
IC & 1.71 & 1.80 & 0.381 & 1.00 & 5.60 \\
SP & 1.72 & 1.75 & 0.389 & 1.00 & 6.50 \\
T & 1.82 & 2.00 & 0.370 & 1.00 & 4.00 \\
I & 1.76 & 1.75 & 0.386 & 1.00 & 4.00 \\
F & 1.83 & 2.00 & 0.417 & 1.00 & 4.00 \\
CP & 1.90 & 2.00 & 0.639 & 1.00 & 4.00 \\
\hline Total & 1.79 & 1.83 & 0.318 & 1.00 & 4.00
\end{tabular}

Notes: The value of 1 represents the highest level of satisfaction, while the value of 4 represents the lowest level, respectively.

The empirical findings, in general, based on the regression analysis suggests diverse roles of demographic factors in explaining the level of satisfaction towards the hajj services in Indonesia. However, the effects are found to be varied among the models, which imply different behavior for each dimension of satisfaction. Table 3 summarizes the estimated coefficients for all regression models.

Table 3 The estimated coefficient of regression models

\begin{tabular}{|c|c|c|c|c|c|c|c|}
\hline \multirow[b]{2}{*}{$\begin{array}{c}\text { Independent } \\
\text { Variable }\end{array}$} & \multicolumn{7}{|c|}{ Dependent Variable } \\
\hline & $\begin{array}{c}\text { IC } \\
\text { (model } \\
\text { 2) }\end{array}$ & $\begin{array}{c}\text { SP } \\
\text { (model } \\
3)\end{array}$ & $\begin{array}{c}T \\
\text { (model } \\
4)\end{array}$ & $\begin{array}{c}\text { I } \\
(\text { model 5) }\end{array}$ & $\begin{array}{c}\text { F } \\
\text { (model 6) }\end{array}$ & $\begin{array}{c}\text { CP } \\
\text { (model 7) }\end{array}$ & $\begin{array}{c}\text { Total } \\
\text { (model } \\
1)\end{array}$ \\
\hline Con & $1.65 * * *$ & $1.63 * * *$ & $1.82 * * *$ & 1.1 & 1.8 & $2.15 * * *$ & $1.74 * * *$ \\
\hline Gender & $-0.035^{*}$ & $-0.043 * *$ & $-0.06^{* * *}$ & $-0.04 * *$ & $-0.035^{*}$ & 0.006 & $-0.03 *$ \\
\hline $\mathrm{Age}$ & 0.005 & 0.00 & -0.009 & 0.004 & $-0.017 *$ & $-0.044 * *$ & -0.005 \\
\hline Married & 0.02 & 0.012 & $0.036^{* *}$ & 0.021 & $0.03 * *$ & 0.017 & 0.02 \\
\hline Educ & 0.004 & $0.012 *$ & $0.013 * *$ & $0.017 * *$ & $0.03 * * *$ & 0.007 & $0.02 * * *$ \\
\hline Job & 0.002 & $0.015 * * *$ & 0.003 & 0.005 & 0.005 & -0.003 & 0.006 \\
\hline Arrival & $0.06 * * *$ & -0.002 & -0.001 & $-0.076^{* * *}$ & $-0.127 * * *$ & $-0.186 * * *$ & $-0.06^{* * *}$ \\
\hline
\end{tabular}

Notes: *Statistically significant at $10 \%$ level of significance, **Statistically significant at $5 \%$ level of significance, $* * *$ Statistically significant at $1 \%$ level of significance

As depicted in Table 3, the estimated coefficients of gender variables are statistically significant at a $5 \%$ level of significance in model 3, 4, and 5, and $10 \%$ level of significance in model 1,2, and 6 . This finding has confirmed Nugraha and Widyaningsih (2021) study on Indonesian Muslim pilgrims, which found that gender significantly moderates the relationship between umroh visit expectation and attitude toward umrah visit. This result suggests that gender may likely have different levels of satisfaction towards the hajj services, particularly for the dimension service procedure (SP), speed of service (T), and ease of access to information. According to the sign of the estimated coefficients, it reveals that females likely experience higher satisfaction than the male.

The age variable is generally found to have no effect on the level of hajj service satisfaction (see model 1). As seen in Table 3, the age variable is only found to have a statistically significant effect on cost perception. According to the negative sign of the estimated coefficient, it suggests that older people are likely to perceive that the cost of hajj service is lower than the younger perception. 104 
According to the Ministry of Religious Affairs, the average cost of hajj service was 35,235,602 rupiahs. As depicted in Table 2, the average score of the cost perception (CP) is 1.90, which implies a moderate perception level. As commonly found in several empirical findings on customer satisfaction, the price remains an important aspect that directly affects the individual level of satisfaction as consistently shown in the case of the pilgrimage industry (Othman et al., 2020; Al Qarni et al., 2013; Kumaladewi et al., 2017). From the economic point of view, the customer's perception of the hajj cost may reflect the willingness to pay to apply for hajj services. The higher cost perception will likely lead to lower demand to apply for hajj services. However, in the case of hajj service in Indonesia, which exclusively relies on the government and considers the religious motivation behind the hajj as an obligatory Muslim activity, the price-demand elasticity of hajj-service might be inelastic.

Like the age variable, the marital status seems not to affect the level of hajj service satisfaction in general (for the total score). However, the findings are different for the dimension of the speed of services and facilities. The positive signs of the estimated coefficient may imply that married people tend to have lower satisfaction towards the hajj services, particularly concerning the speed of services and the quality of facilities. This finding suggests that providing good quality facilities and fastresponse services does matter since most of the Indonesian hajj pilgrims are married.

As seen in Table 3, compared to other demographic variables, the education level has a significant effect on most models. According to the results of model 1, it suggests that level of education has a substantial impact on the total score of hajj service satisfaction. The finding is also confirmed by the role of education on the satisfaction level towards the dimension of the speed of services, the ease of access to information and facilities. The empirical results suggest that people with higher levels of education tend to have less level of satisfaction. This finding confirms that more education will lead to higher expectations towards public services, resulting in lower satisfaction. In other words, more educated people tend to have higher standards, particularly regarding the public services.

Similar to the effect of age and marital status, the type of job variable is found to have no significant impact on the hajj service satisfaction in general (model 1). However, the type of job is statistically significant in model 3, which implies its role on the level of satisfaction towards the dimension of service procedure. As described in Table 1, according to this finding, it suggests that there are different perceptions on the service procedure across the type of job.

\section{CONCLUSION}

Analysis of the national hajj survey in 2019 reveals that the level of hajj service satisfaction is relatively good, covering the dimension of individual capacity, service procedure, speed of services, ease of access to information, facilities and infrastructure, and cost perception. The individual capability dimension and the service procedure are the two most satisfying dimensions with the lowest value than any other dimensions. Meanwhile, the cost perception has the highest score, which implies the least satisfaction. According to this finding, it is suggested that the government should reflect on the calculation of hajj services costs as room for improvement.

Furthermore, the regression analysis results reveal diverse impacts of demographic factors on the level of hajj-related service satisfaction. Those effects remain different for each dimension of satisfaction. Gender and level of education have the most significant impact on the level of hajj service satisfaction. The empirical findings suggest that people with higher-level education are more likely to experience less satisfaction. Meanwhile, females are likely to perceive higher satisfaction than males.

Further studies are required to improve our understanding of the price-demand elasticity of hajjservice, especially related to individual willingness to pay. Does the assumption of seeing hajj as an obligatory religious activity to be performed at any cost matter? It would be very interesting to 
conduct longitudinal studies to examine the relationship of the two variables (price-demand elasticity and individual religious motivation) over time.

\section{REFERENCES}

Abdi, A. P. (2019). Kemenkes: 60 Persen Lebih Calon Jamaah Haji 2019 Lansia [Internet]. [accessed on 2019 Jun 12]. Retrieved from https://tirto.id/kemenkes-60-persen-lebih-calon-jamaah-haji2019-lansia-eciN.

Al-Qarni, A.A., Alsharqi, O.Z., Qalai, D.A. \& Kadi, N. (2013). The impact of marketing mix strategy on hospitals performance measured by patient satisfaction: An empirical investigation on Jeddah private sector hospital senior managers perspective. International Journal of Marketing Studies, 5(6), 210-227.

Berry, L. L., Zeithaml, V. A. \& Parasuraman, A. (1990). Five imperatives for improving service quality. MIT Sloan Management Review, 31(4), 29.

Brysland, A. \& Curry, A. (2001). Service improvements in public services using SERVQUAL. Managing Service Quality: An International Journal.

Bouckaert, G., De Walle, S.V. \& Kampen, J. K. (2005). Potential for comparative public opinion research in public administration. International Review of Administrative Sciences, 71(2), 229240.

Christensen, T., Yamamoto, K. \& Aoyagi, S. (2020). Trust in local government: Service satisfaction, culture, and demography. Administration \& Society, 52(8), 1268-1296.

Collins, B. K., Kim, H. J., \& Tao, J. (2019). Managing for citizen satisfaction: Is good not enough?. Journal of Public and Nonprofit Affairs, 5(1), 21-38.

De Walle, S.V. (2018). Explaining citizen satisfaction and dissatisfaction with public services. The Palgrave Handbook of Public Administration and Management in Europe, 227-241.

Donnelly, M., Wisniewski, M., Dalrymple, J. F. \& Curry, A. C. (1995). Measuring service quality in local government: The SERVQUAL approach. International Journal of Public Sector Management.

Kampen, J. K., De Walle, S. V., \& Bouckaert, G. (2006). Assessing the relation between satisfaction with public service delivery and trust in government. The impact of the predisposition of citizens toward government on evalutations of its performance. Public Performance \& Management Review, 29(4), 387-404.

Kumaladewi, N., Anas, M., Ratnawati, S., Huda, M. Q. \& Durachman, Y. (2017, August). Pilgrimage organizers monitoring system to improve umrah services (Case study: Sub directorate of umrah development of the ministry of religious affairs of the republic of Indonesia). In 5th International Conference on Cyber and IT Service Management (CITSM) (pp. 1-4). IEEE.

Martinović, M., Pavlić, I. \& Šuman Tolić, M. (2017). Measurement of local public services' quality using SERVQUAL: The case of Dubrovnik. Ekonomska misao i praksa, (2), 593-610.

Ministry of Administrative Reform (2017). Peraturan Menteri Pendayagunaan Aparatur Negara dan Reformasi Birokrasi Republik Indonesia Nomor 14 Tahun 2017 tentang Pedoman Penyusunan Survei Kepuasan Masyarakat Unit Penyelenggara Pelayanan Publik.

Ministry of Religious Affairs (2019). Executive Summary: Survei Kepuasan Pelayanan Haji Di Indonesia Tahun 2019H/2018M [Internet]. [accessed on 2019 Aug 24]. Retrieved from https://simlitbangdiklat.kemenag.go.id/simlitbang/spdata/upload/dokumen-penelitian/15577994 13SURVEI_KEPUASAN_PELAYANAN_HAJI_DI_INDONESIA_TAHUN_2019H2018M.p df.

Murtin, F., Fleischer, L., Siegerink, V., Aassve, A., Algan, Y., Boarini, R. \& Kim, S. (2018). Trust and its determinants: Evidence from the Trustlab experiment.

Nicholls, J. A. F., Gilbert, G. R. \& Roslow, S. (1998). Parsimonious measurement of customer satisfaction with personal service and the service setting. Journal of Consumer Marketing.

Nugraha, Y.D. \& Widyaningsih, Y.A. (2021). The moderating role of gender and religiosity on the EMA model: an Indonesian Muslim pilgrim perspective. Journal of Islamic Marketing. https:// doi.org/10.1108/JIMA-03-2020-0076. 
Othman, B. A., Harun, A., De Almeida, N. M. \& Sadq, Z. M. (2020). The effects on customer satisfaction and customer loyalty by integrating marketing communication and after sale service into the traditional marketing mix model of umrah travel services in Malaysia. Journal of Islamic Marketing.

Psomas, E., Bouranta, N., Koemtzi, M., \& Keramida, E. (2020). Determining the impact of service quality on citizens' satisfaction and the role of citizens' demographics. The case of the Greek citizen's service centers. The TQM Journal.

Radu, G., Radu, M., Condurache, A. \& Purcărea, V. L. (2018). Managerial strategies and policiesAnalysis of patient satisfaction based on demographic data. Journal of Medicine and Life, 11(3), 218.

Rouf, M. A., Kamal, M. \& Iqbal, M. M. (2018). Customers' perception of service quality of banking sectors in Bangladesh. International Journal of Law and Management.

Setiawan, M. H. (2019). Jamaah Haji Naik 4,96\%, Jumlah Total Capai 2,4 Juta Lebih [Internet]. [accessed on 2019 Aug 24]. Retrieved from https://www.jawapos.com/nasional/24/08/2019/ jamaah-haji-naik-496-persen-jumlah-total-capai-24-juta-lebih/.

Shockley-Zalabak, P. S., Morreale, S. \& Hackman, M. (2010). Building the High-Trust Organization: Strategies for Supporting Five Key Dimensions of Trust. Hoboken (US), John Wiley \& Sons.

Tjiptono, F., \& Chandra, G. (2005). Service, Quality dan Satisfaction. Yogyakarta (ID), Andi Offset.

Tjiptono, F. (2002). Strategi Pemasaran. Yogyakarta (ID), Andi Offset.

Vigoda-Gadot, E. \& Yuval, F. (2003). Managerial quality, administrative performance and trust in governance revisited: A follow-up study of causality. International Journal of Public Sector Management.

Yang, K. \& Holzer, M. (2006). The performance-trust link: Implications for performance measurement. Public Administration Review, 66(1), 114-126.

Young, G. J., Meterko, M. \& Desai, K. R. (2000). Patient satisfaction with hospital care: effects of demographic and institutional characteristics. Medical Care, 325-334.

Zeithaml, V. A., Bitner, M. J., \& Gremler, D. D. (2018). Services Marketing: Integrating Customer Focus Across the Firm. New York (US), McGraw-Hill Education. 